\title{
A NOVEL POROUS ACTIVATED CARBON COMPOUND PREPARED FOR ADSORPTION OF COBALT (CO (II)) FROM AQUEOUS SOLUTION FOR ENVIRONMENTAL POLLUTION MITIGATION
}

\author{
Pramod Kamble ${ }^{1, *}$ Rupali H. Landge ${ }^{1}$, Abhijit N. Lande ${ }^{1}$ \\ and Vinayak P. Dhulap ${ }^{2}$ \\ ${ }^{1}$ Department of Environmental Sciences, Savitribai Phule Pune University, Pune 411007 \\ ${ }^{2}$ Department of Environmental Science, School of Earth Sciences, \\ Solapur University, Solapur-413 255 \\ *E-mail: kpramod09@gmail.com
}

\begin{abstract}
The eco-friendly and sustainable technique was developed to resolve the problem of heavy metal pollution. In the present study, the removal of cobalt (Co (II)) was carried out using the activated carbon (AC). Activated carbon compound was prepared using selected plants such as Ficus benghalensis (FB), Mangifera indica (MI), Tamarindus indica (TI), Azadirachta indica (AI) and Syzygium cumini (SC). The characterization of the products was done by using the scanning electronic microscope (SEM) in order to know the microstructure of AC. It shows that prepared activated carbons (PACs) are porous in nature having the elevated surface area for effective adsorption and applicable for the mitigation of heavy metals. The study involves the effect of dose, concentration and contact time for removal of Co (II) and to assess the efficiency of PACs. The results reveal that the adsorption of Co (II) observed to be highest at 5g PAC-AI, PAC-MI and $6 \mathrm{~g}$ for PAC-TI, PAC-FB, PAC-SC dose, respectively. Maximum adsorption was exhibited in a solution containing $25 \mathrm{mg} / \mathrm{L}$ concentration of Co (II) after addition of a mixed dose of PACs. The comparable adsorption was observed at contact time for PAC-AI, PAC-TI, PAC-FB, PAC-SC at 120 minutes and PAC-MI for 30 minutes respectively. Moreover, it is a need for continuous monitoring and further research for the development of an eco-friendly and advanced method to remove heavy metals.
\end{abstract}

Keywords: Cobalt (Co (II)), Porous activated carbon, Bio-adsorbent, Plant material

(C) RASĀYAN. All rights reserved

\section{INTRODUCTION}

Anthropogenic activities are mostly responsible for causing serious threats to environmental spheres such as air, land, and water. The rapid industrial development is the main cause of increase in concentration of heavy metals and their disposal into the environment. It is important to mention that more than 20 heavy metals are considered lethal, and fifty percent of these are discharged into the environment in a huge quantity and that can pose dire consequences on human health. ${ }^{1}$ The numbers of conventional methods have been developed over the last few years for the removal of heavy metals from industrial wastewater. The predominant methods are coagulation and flocculation. ${ }^{2}$ Other traditional techniques were used for removal of heavy metal ions from aqueous solutions are chemical precipitation, ion exchange, chemical oxidation/reduction, reverse osmosis, electrodialysis, ultrafiltration, etc. However, these methods have their own limitations such as less efficiency, sensitive operating conditions, production of secondary sludge and also the disposal is a costly affair. ${ }^{3}$ The precipitation, ion exchange, electrochemical processes, and membrane technology are well-known chemical methods that are economically not feasible and less competent than the biosorption process. ${ }^{4}$ Moreover, these methods create environmental pollution by increasing the pollution load of heavy metals through the disposal of byproduct. ${ }^{1}$

The cost-effective and non-conventional adsorbents such as agriculture byproducts such as nutshells, wood, bone, peat coconut shells have converted into activated carbons and biomass like Aspergillus tereus, Rhizopus aehizus. ${ }^{1,5,6}$ However, these materials can be used as effective adsorbents for the Rasayan J. Chem., 12(4), 1864-1871(2019) http://dx.doi.org/10.31788/RJC.2019.1245324 
RASĀYAN J. Chem.

Vol. 12 | No. 4 |1864 - 1871| October - December | 2019

removal of heavy metals and the organic toxic compound from municipal and industrial wastewater. ${ }^{1,5}$ Although the lethal heavy metals ions are discharged into the aquatic streams through the various anthropogenic activities such as mining, refining ores, fertilizer industries, tanneries, batteries, smelting industries, metal plating, tanneries paper industries, pesticides, etc. creating dire consequences to the environment. ${ }^{7,8}$ The major toxic metals ions hazardous to humans as well as other forms of life are $\mathrm{Cr}, \mathrm{Fe}$, $\mathrm{Se}, \mathrm{V}, \mathrm{Cu}, \mathrm{Co}, \mathrm{Ni}, \mathrm{Cd}, \mathrm{As}, \mathrm{Pb}, \mathrm{Zn}$, etc ${ }^{7,8}$ and most of them bear the carcinogenic property when present in an excess amount. ${ }^{9}$ The heavy metals are naturally found in the earth's environment and ecosystem. ${ }^{10}$ Anthropogenic activities are mainly responsible for the increase in their concentration in environment and they can enter into the plant, animal, and human tissues via inhalation, diet, and rough handling. ${ }^{10}$ They can bind and interfere with the functioning of vital cellular components. ${ }^{10}$ Research-based on the treatment of effluent containing heavy metals has indicated that adsorption is considered and widely used method, for the mitigation of heavy metals from the waste watercourse. Activated carbon has been wellknown adsorbent and it has been widely used for the removal of heavy metal and purification of the wastewater. However, activated carbon remains costly stuff. ${ }^{10,11}$

Hence, it is necessary to develop safe and economic feasible methods for the removal of heavy metals from industrial contaminated waters. ${ }^{10}$ Thus, it is essential to carry out further research to produce low cost activated carbon from agricultural leftover by-products. ${ }^{10,11}$ In general, an adsorbent can be considered as a cost-effective adsorbent. ${ }^{12-13}$ However, the porous material can decide the efficiency of adsorption of metal on prepared activated carbon (PACs). ${ }^{6,14}$ The porosity of activated carbon increases the surface area for better adsorption. ${ }^{6}$

With this backdrop, the objective of our study was to develop the feasibility using porous carbonized plant material for the removal of Co (II) from the prepared aqueous solution. Although many studies have been carried out on this topic, no study has been made on different plant material which is easily available and mixed PACs dose effect on the concentration of Co (II). Activated carbon is widely used and applicable for removal of heavy metal from the aquatic environment due to its porous quality. ${ }^{15-17}$ Cobalt is an important trace element and actively participates in the vitamin B12 formation process. The requirement of Cobalt $(\mathrm{Co})$ for human health is in micro quantity i.e. $1 \mathrm{mg} / \mathrm{l}$. Cobalt salts small dose can be helpful to overcome with the problem of mineral deficiencies in certain animals. Cobalt is also bearing a carcinogenic property if given in large doses, and as a good reducing agent; it seldom appears in pure forms. ${ }^{18}$

\section{Materials}

\section{EXPERIMENTAL}

Plant bark of Ficus benghalensis, Syzygium cumini, Azadirachta indica, Tamarindus indica, Mangifera indica were collected from Savitribai Phule Pune University campus, Alice Garden located at a latitude of $18.52^{\circ}$ North, the longitude of $73.85^{\circ}$ East at an altitude of 560 meters $(1,837$ feet $)$ above sea level. The average annual precipitation is about $722 \mathrm{~mm}$ and the average temperature in Pune is $25^{\circ} \mathrm{C}$. The average annual relative humidity is 59 to $64 \%$.

\section{Collection of Raw Material for Production of Coal}

The Method develops by Nwabanne and Igbokwe, ${ }^{19}$ were followed for the production of porous activated carbon. In the present study, plant barks were cut into small pieces of 2-3 cm size, dried in sunlight, then grounded using the grinder, and passed into $2 \mathrm{~mm}$ mesh size sieve. The dried material was then soaked in a hot solution of $10 \%$ Phosphoric acid for an hour and dried at room temperature for $24 \mathrm{hr}^{10,20}$ Carbonization and activation of the material was carried out in a muffle furnace at $400{ }^{\circ} \mathrm{C}$ for $1 \mathrm{hr}$ and subsequently washed with distilled water. The residual char was also ground using mortar and pestle to make powder. A subsequently powdered content was again heated at $600^{\circ} \mathrm{C}$ in a muffle furnace for 10 min for getting the product ${ }^{10,20}$ (Fig.-1).

Ash content

Ash percentage was determined according to Kamble et al., ${ }^{19}$

\section{Moisture content}

It was determined by according to Kamble et al. ${ }^{19}$ 


\section{SEM (Scanning Electron Microscope) Analysis}

In order to know the size distribution of micropores of activated carbon and to understand its important characteristics to estimate its applicability as an adsorbent, ${ }^{6,21}$ SEM analysis was carried out. The microstructure of all PACs has been studied using SEM instrument (JEOL model no. JSM-6360 Microscope).

\section{Plant Material}

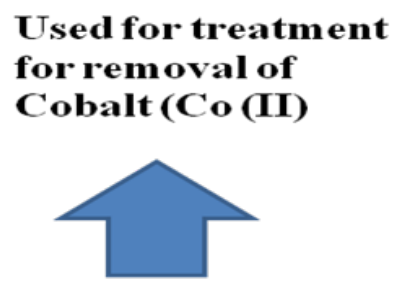

SEM analysis

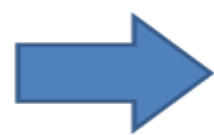

Plant material dried and Grinded

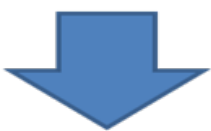

Soaked in boiled $10 \%$

Phosphoric acid and dried at room temperature for $24 \mathrm{hr}$.

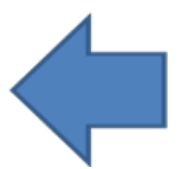

Fig.-1: Experimental Design

Experimental Setup and Methodology

\section{Preparation of Stock Solution}

The stock solution of Co (II) $(100 \mathrm{mg} / \mathrm{L})$ was prepared in the laboratory by dissolving $3.10 \mathrm{mg}$ of cobalt nitrate in $1000 \mathrm{ml}$ distilled water. The stock solution was stored in a sample bottle at room temperature. ${ }^{10,20}$

\section{Batch Study}

In the present experiments, Batch adsorption study was conducted. The porous activated carbon obtained from locally available plant materials such as Ficus benghalensis (PAC- FB), Syzygium cumini (PAC$\mathrm{SC})$, Azadirachta indica (PAC- AI), Tamarindus indica (PAC- TI) and Mangifera indica (PAC- MI), has been used in order to study removal of Co (II) from aqueous solution. A batch adsorption study was conducted at various doses $(1,2,3,4,5$, and 6), concentration $(25,50,75,100 \mathrm{mg} / \mathrm{L})$ and contact time $(30,60,90,120 \mathrm{~min})$. The contents were kept in separate conical flasks of $250 \mathrm{ml}$ capacity. Contents of the flasks were well mixed using control shaking for $2 \mathrm{~h}$ and subsequently filtered through whatman 42 and finally taken for analysis of Co (II) using atomic absorption spectrometer (Shimadzu AA-7000). ${ }^{10,20}$

\section{Effect of Doses on Adsorption}

Various doses of the adsorbent PACs were added at the various rate of $1 \mathrm{~g}, 2 \mathrm{~g}, 3 \mathrm{~g}, 4 \mathrm{~g}, 5 \mathrm{~g}, 6 \mathrm{~g}$ to each conical flask respectively and kept on the shaker for $2 \mathrm{~h}$. Co (II) solution of $100 \mathrm{mg} / \mathrm{L}$ was added in the flasks. $^{20}$

\section{Effect of Co (II) Concentration on Adsorption}

$100 \mathrm{ml}$ solution of Co (II) of different concentrations of $25 \mathrm{mg} / \mathrm{L}, 50 \mathrm{mg} / \mathrm{L}, 75 \mathrm{mg} / \mathrm{L}$, and $100 \mathrm{mg} / \mathrm{L}$ of Co (II) solution was taken in 5 different flasks in duplicate. The adsorbent optimum dose of activated carbon $1 \mathrm{~g}, 2 \mathrm{~g}, 3 \mathrm{~g}, 4 \mathrm{~g}, 5 \mathrm{~g}, 6 \mathrm{~g}$, of PAC-FB, PAC-SC, PAC-AI, PAC-TI, and PAC-MI was added respectively into each conical flask containing the solution and subsequently treated for $2 \mathrm{~h}^{20}$

\section{Effect of Contact Time on Adsorption}

The adsorbent dose of activated carbon 1g, 2g, 3g, 4g, 5g, 6g of (PAC-FB), (PAC-SC), (PAC-AI), (PACTI), ( PAC-MI) respectively were added in replicate to the metal solution and kept for 30, 60, 90 and 120 min interval to see the impact of contact time. ${ }^{20}$ 
RASĀYAN J. Chem.

Vol. 12 | No. 4 |1864 - 1871| October - December | 2019

\section{Statistical Analysis}

The average values and standard errors have been calculated using statistical methods.

\section{Scanning Electron Microscope Analysis}

\section{RESULTS AND DISCUSSION}

Figure-1 showed the observed microstructure for PAC-TI and PAC-AI are heterogeneity in nature and showed porous nature having approximately $5 \mu \mathrm{m}$ pore size (Fig.-1C and D). The activated carbon had an irregular porous surface, indicating relatively high surface areas. ${ }^{6,21}$ PAC-FB has shown no aggregation of particles, no symmetrical aggregation and was porous in nature (Fig.-1A). In the case of PAC-MI it has shown heterogeneity, $5 \mu \mathrm{m}$ pore size, and porous nature and symmetrical aggregation (Fig.-1E). PAC-SC has shown aggregation in layers and heterogeneity (Fig.-1B). All the PACs are effective for removal of cobalt (Co (II)) from aqueous solution.
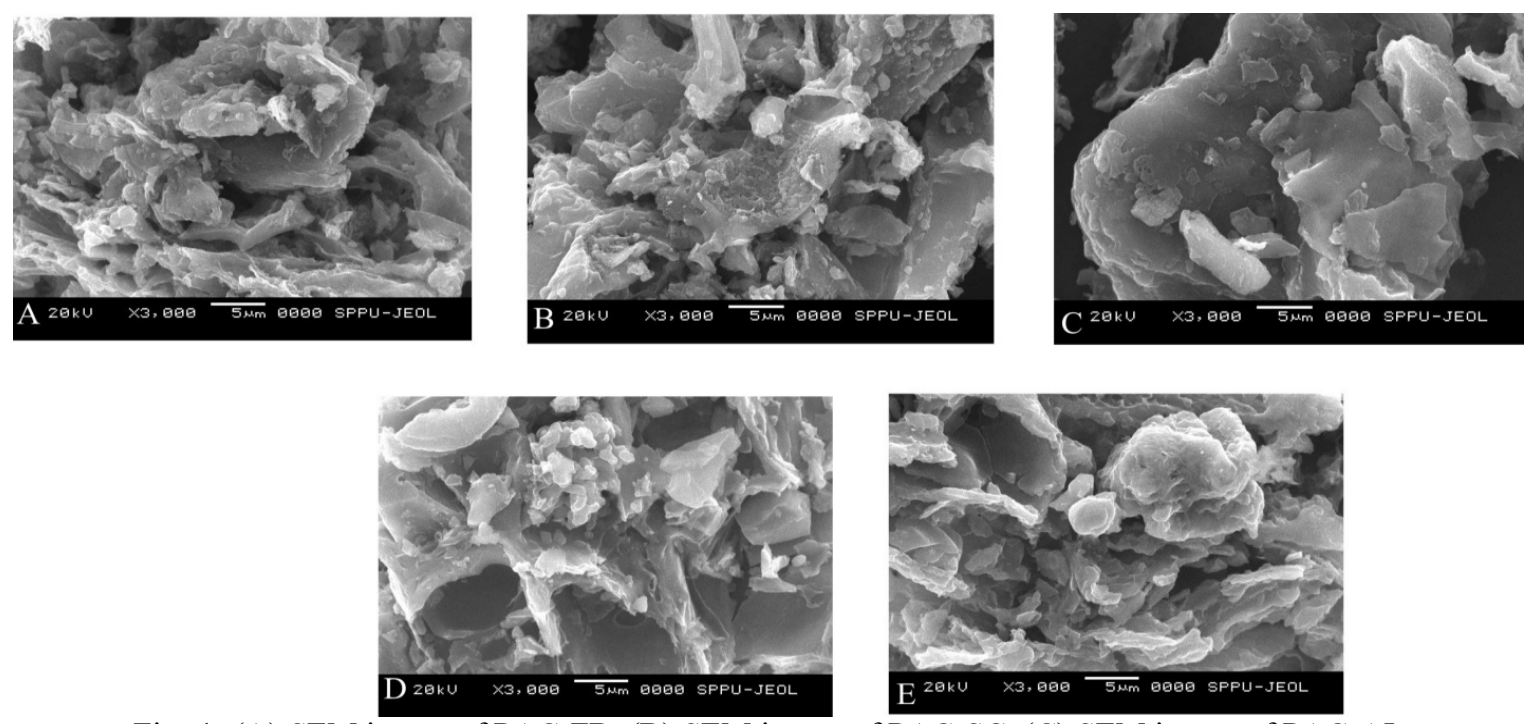

Fig.-1: (A) SEM image of PAC-FB, (B) SEM image of PAC-SC, (C) SEM image of PAC-AI,

(D) SEM image of PAC-TI and (E) SEM image of PAC-MI

\section{Characterization of Activated Carbon Compound}

The moisture content of PAC-FB, PAC-SC, PAC-AI, PAC-TI, and PAC-MI observed to be $45.1 \%$, $14.03 \%, 12.14 \%, 3 \%, 8.8 \%$ respectively (Table-1). The moisture content is one of the very important parameters and plays a very crucial role in maintaining the adsorption efficiency of activated carbon. It is necessary to have enough dried activated carbon for adsorption of any material. ${ }^{22}$ Several authors have argued that the excess moisture content fills the micropores or active adsorption sites, which led to decrease in adsorption capacity of prepared activated carbon. ${ }^{23-26}$ Ash content of PAC-FB, PAC-SC, PAC-AI, PAC-TI, and PAC-MI observed to be $67.69 \%, 31.64 \%, 59.7 \%, 72.30 \%$ and $66.6 \%$ (Table- 1 ) respectively. It has been stated that the amount of carbon content is inversely proportional to the ash content of the any prepared activated carbon. ${ }^{27}$

\section{Effect of Dose on Adsorption of Co (II)}

In case of different dosage, after treatment the concentration of Co (II) with PAC-FB at 1, 2, 3, 4, 5 and $6 \mathrm{~g} / 100 \mathrm{ml}$ was $62.06( \pm 1.8), 49.04( \pm 3.8), 41.46( \pm 5.4), 44.81( \pm 2.1), 42.42( \pm 3.8), 40.26( \pm 0.3) \mathrm{mg} / 1$ respectively. The optimum dose for removal of cobalt was $6 \mathrm{~g}$. However, in case of PAC-SC the residual concentration was found to be $67.85( \pm 4.3), 53.55( \pm 2.6), 62.24( \pm 1.5), 56.56( \pm 1.4), 69.1( \pm 3.3) \mathrm{mg} / \mathrm{l}$ (Table-3). The optimum dose was found to be $2 \mathrm{~g}$. In case of PAC-AI it was $59.6( \pm 4.3), 52.18( \pm 2.6)$, $51.01( \pm 1.5), 41.17( \pm 5.3), 31.08( \pm 1.4), 35.6( \pm 3.3) \mathrm{mg} / \mathrm{l}$. The optimum dose was found to be $5 \mathrm{~g}$. In case of (PAC-TI) it was $74.38( \pm 1.7), 59.27( \pm 0.1), 46.56( \pm 8.8), 54.42( \pm 8.2) 45.56( \pm 7.5), 36.84( \pm 0.4) \mathrm{mg} / \mathrm{l}$. The optimum dose was found to be $5 \mathrm{~g}$. In case of (PAC-MI) it was $65.61( \pm 4), 63.41( \pm 2.6), 62.84$ 
RASĀYAN J. Chem.

Vol. 12 | No. 4 |1864 - 1871| October - December | 2019

( \pm 3.2$), 56.77( \pm 5.9), 51.15( \pm 6.2), 61.4( \pm 4.6) \mathrm{mg} / \mathrm{l}$. Optimum dose was found to be $6 \mathrm{~g}$ (Table 3$)$. The highest removal percentage of Co (II) was found at $6 \mathrm{~g}$ in PAC-FB $(59.74 \% \pm 0.76)$, PAC-SC $(54.77 \%$ $\pm 1.68)$, PAC-TI $(63.15 \% \pm 0.42)$ while maximum efficiency was found at $5 \mathrm{~g}$ in PAC-AI $(68.92 \% \pm 1.68)$ and PAC-MI (48.85\% \pm 6.26$)$ (Fig.-2A).

Table-1: Ash Content and Moisture Content

\begin{tabular}{c|c|c}
\hline PACs & Ash Content & Moisture Contents \\
\hline Ficus benghalensis (PAC-FB) & $67.69 \%$ & $45.1 \%$ \\
\hline Syzygium cumini (PAC-SC) & $31.64 \%$ & $14.03 \%$ \\
\hline Azadirachta Indica (PAC-AI) & $72.30 \%$ & $12.14 \%$ \\
\hline Tamarindus indica (PAC-TA) & $59.7 \%$ & $3.00 \%$ \\
\hline Mangifera indica (PAC-MI) & $66.6 \%$ & $8.8 \%$ \\
\hline
\end{tabular}

However, the minimum residual concentration was observed after addition of PAC-AI and PAC-TI at $6 \mathrm{~g}$ of optimum dose. The possible explanation could be that the SEM analysis data had shown higher porosity, heterogeneity nature and symmetrical aggregation in PAC-AI and PAC-TI than that of other PACs. Moreover, the increasing amount of doses from 1 to $6 \mathrm{~g}$ showed increase in CO (II) adsorption in almost all PACs. The possible explanation could be for this was due to increasing the adsorptive surface area and the availability of extra adsorption sites to adsorb Co (II) ${ }^{28-29}$ The results of the present investigation support the above explanation.

Table-2: Residual Concentration of Co (II) in mg/L after Treatment at Different Doses of Activated Carbon

\begin{tabular}{c|c|c|c|c|c|c}
\hline \multirow{2}{*}{$\begin{array}{c}\text { Name of } \\
\text { Adsorbent }\end{array}$} & \multicolumn{6}{|c}{ Initial Concentration of Co $100 \mathrm{mg} / \mathrm{L}$} \\
\cline { 2 - 7 } & $1 \mathrm{~g}$ & $2 \mathrm{~g}$ & $3 \mathrm{~g}$ & $4 \mathrm{~g}$ & $5 \mathrm{~g}$ & $6 \mathrm{~g}$ \\
\hline PAC-FB & $62.06( \pm 1.8)$ & $49.04( \pm 3.8)$ & $41.46( \pm 5.4)$ & $44.81( \pm 2.1)$ & $42.42( \pm 3.8)$ & $40.26( \pm 0.3)$ \\
\hline PAC-SC & $67.85( \pm 4.3)$ & $53.55( \pm 2.6)$ & $62.24( \pm 1.5)$ & $59.26( \pm 5.3)$ & $56.56( \pm 1.4)$ & $6.91( \pm 3.3)$ \\
\hline PAC-AI & $59.6( \pm 4.3)$ & $52.18( \pm 2.6)$ & $51.01( \pm 1.5)$ & $41.17( \pm 5.3)$ & $31.08( \pm 1.4)$ & $35.6( \pm 3.3)$ \\
\hline PAC-TI & $74.38( \pm 1.7)$ & $59.27( \pm 0.1)$ & $46.56( \pm 8.8)$ & $54.42( \pm 8.2)$ & $45.56( \pm 7.5)$ & $36.84( \pm 0.4)$ \\
\hline PAC-MI & $65.61( \pm 4)$ & $63.41( \pm 2.6)$ & $62.84( \pm 3.2)$ & $56.77( \pm 5.9)$ & $51.15( \pm 6.2)$ & $61.4( \pm 4.6)$ \\
\hline
\end{tabular}

\section{Effect of Contact Time on Adsorption of Co (II)}

Four different time intervals were used i. e. 30, 60, 90 and 120 minutes. In the case of (PAC-FB), it was $70.13( \pm 3.3) 73.67( \pm 0.5), 74.21( \pm 0.7), 67.57( \pm 0.9) \mathrm{mg} / \mathrm{l}$. In the case of (PAC-SC), it was $67.27( \pm 0.6)$, $68.9( \pm 0.9), 67.27( \pm 1.0), 54.33( \pm 9.7) \mathrm{mg} / \mathrm{l}$. In case of ( PAC-AI) it was $72.5( \pm 0.4), 68.7( \pm 1.5), 67$ $( \pm 0.8), 66.7( \pm 1.6)$ In case of ( PAC-TI), it was $52.10( \pm 1.3), 64.64( \pm 3.8), 53.97( \pm 1.5), 42.8( \pm 10.8)$ $\mathrm{mg} / \mathrm{l}$. In the case of (PAC-MI), it was $61.70( \pm 9.9), 71.23( \pm 0.1), 70.69( \pm 0.5), 67.31( \pm 1.8) \mathrm{mg} / \mathrm{l}$ (Table4). Optimum time was found to be $120 \mathrm{~min}$ in PAC-FB $(32.42 \% \pm 0.9)$, PAC-SC $(32.42 \% \pm 0.9)$, for PACTI $(57.1 \% \pm 10.85)$. In the case of PAC-AI $(32.97 \% \pm 0.80)$, it was $90 \mathrm{~min}$ while in case of PAC-MI $(32.42 \% \pm 0.9)$ it was 30 min (Fig.-2B). However, many studies revealed that the increasing contact time has led to increase in adsorption of metal ${ }^{30,20}$ but remains stable with a further increase in contact time. ${ }^{29}$ Our results had shown the same trend for contact time.

\section{Effect of Concentration on Adsorption of CO (II)}

After treatment, the residual concentration of Co (II) with mixed all plants (PAC-TI), (PAC-MI), (PACAI), (PAC-FB), (PAC-SC) was $13.47( \pm 3.8), 17.84( \pm 0.9), 31.04( \pm 0.1), 33.16( \pm 2.1)$ (Table-4). Optimum concentration was found to be $25 \mathrm{mg} / \mathrm{l}$. However, the mixed treatment of all PAC has resulted in highest removal efficiency and it was found to be $86.53( \pm 3.86), 82.10( \pm 0.90), 68.96( \pm 0.14)$ and $66.83 \%( \pm 2.15)$ at $25,50,75$ and $100 \mathrm{mg} / 1$ respectively. The maximum removal capacity was found at $25 \mathrm{mg} / \mathrm{lof}$ concentration (Fig.-2D). However many studies have been made and revealed that maximum adsorption of metal occurred at a low concentration of metal. ${ }^{30,31}$ In the present case, it was $25 \mathrm{mg} / 1$ while in case of Karnib et $\mathrm{al}^{15}$ was $30 \mathrm{mg} / \mathrm{l}$. Same results has been observed by Kamble et al. ${ }^{20}$ adsorption was maximum at PACC $(90.5 \%)>$ PACB $(87.5 \%)>$ CAC $(85.5 \%)$ in a solution containing $25 \mathrm{mg} / \mathrm{l}$ concentration of $\mathrm{Cu}$ for all PACs. ${ }^{20}$ The possible explanation could be that the adsorption efficiency has decreased with increasing concentration of metal in solution. ${ }^{32,33}$ Moreover, it could be because of low concentration of 
RASĀYAN J. Chem.

Vol. 12 | No. 4 |1864 - 1871| October - December | 2019

metals are being absorbed by explicit sites and with increasing metal concentrations the explicit sites became saturated and the exchange sites of PACs got filled, which ultimately resulted in very less adsorption efficiency. ${ }^{34}$
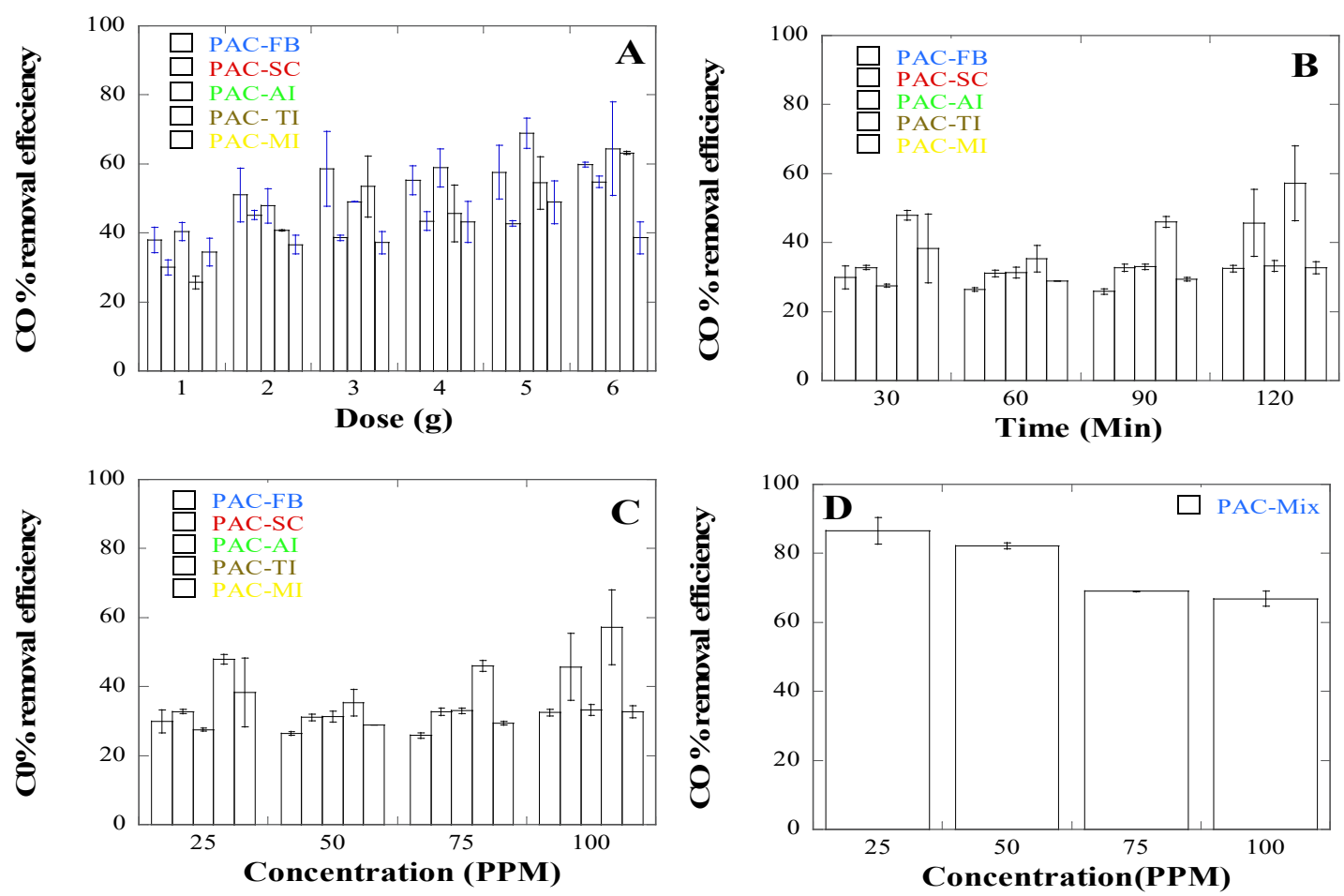

Fig.-2: (A) Effect of Dose on Co (II) Removal on Adsorbent, (B) Effect of Contact Time on Removal of Co (II) on Adsorbent, (C) Effect of Concentration on Co (II) Removal on Adsorbent, (D) Effect of Concentration on Co (II) Removal on Mixed Adsorbent

Table-3: Residual Concentration of Co (II) in mg/L after Treatment with Different Time

\begin{tabular}{c|c|c|c|c}
\hline \multirow{2}{*}{$\begin{array}{c}\text { Name of } \\
\text { Adsorbent }\end{array}$} & \multicolumn{4}{|c}{ Initial Concentration $100 \mathrm{mg} / \mathrm{L}$} \\
\cline { 2 - 5 } & $30 \mathrm{~min}$ & $60 \mathrm{~min}$ & $90 \mathrm{~min}$ & $120 \mathrm{~min}$ \\
\hline PAC-FB & $70.13( \pm 3.3)$ & $73.67( \pm 0.5)$ & $74.21( \pm 0.7)$ & $67.57( \pm 0.9)$ \\
\hline PAC-SC & $67.27( \pm 0.6)$ & $68.9( \pm 0.9)$ & $67.27( \pm 1.0)$ & $54.33( \pm 9.7)$ \\
\hline PAC-AI & $72.5( \pm 0.4)$ & $68.7( \pm 1.5)$ & $67( \pm 0.8)$ & $66.7( \pm 1.6)$ \\
\hline PAC-TI & $52.10( \pm 1.3)$ & $64.64( \pm 3.8)$ & $53.97( \pm 1.5)$ & $42.8( \pm 10.8)$ \\
\hline PAC-MI & $61.70( \pm 9.9)$ & $71.23( \pm 0.1)$ & $70.69( \pm 0.5)$ & $67.31( \pm 1.8)$ \\
\hline
\end{tabular}

Table-4: Residual Concentration of Co (II) in $\mathrm{mg} / \mathrm{L}$ after Treatment with increasing Concentration of Co (II)

\begin{tabular}{c|c|c|c|c}
\hline \multirow{2}{*}{ Name of Adsorbent } & \multicolumn{4}{|c}{ Concentration of Co (II) } \\
\cline { 2 - 5 } & $25 \mathrm{mg} / \mathrm{L}$ & $50 \mathrm{mg} / \mathrm{L}$ & $75 \mathrm{mg} / \mathrm{L}$ & $100 \mathrm{mg} / \mathrm{L}$ \\
\hline Mixed all plants & $13.47( \pm 3.8)$ & $17.84( \pm 0.9)$ & $31.04( \pm 0.1)$ & $33.16( \pm 2.1)$ \\
\hline
\end{tabular}

\section{CONCLUSION}

Several techniques may be employed for the treatment of wastewater and the removal of Cobalt. It is crucial to choose the most appropriate treatment for metal, which is based on basic concentration, contact time and amount of adsorbent. There is a strong need for eco-friendly or bio-treatment methods for removal of the harmful environmental impact of heavy metal. The best optimum contact time for the 
RASĀYAN J. Chem.

Vol. 12 | No. 4 |1864 - 1871| October - December | 2019

cobalt removal was $120 \mathrm{~min}$ for PAC-AI, PAC-TI, PAC-FB, PAC- SC and $30 \mathrm{~min}$ for PAC-MI. The best optimum concentrations for the Co (II) removal were $25 \mathrm{mg} / 1$ and $5 \mathrm{~g}$ (PAC-AI), (PAC-MI), $6 \mathrm{~g}$ (PAC- TI), (PAC- FB), (PAC-SC) of dose of activated carbon. However, the combination of all PACs showed higher efficiency than individual treatment. The use of activated carbon is a promising and innovative technique for clean and efficient treatment.

\section{ACKNOWLEDGMENT}

Authors are thankful to Head Department of Environmental Science, SPPU, Pune for providing necessary laboratory facilities and Dr. Praveen Saptarshi, Emeritus Professor for his valuable guidance.

\section{REFERENCES}

1. O. S. Amuda, A. Giwa, Bello I.A., Biochem. Eng. J., 36,174(2007), DOI: 10.1016/j.bej.2007.02.013

2. P. Rajasulochana and V. Preethy, Reso.-Effici. Technol., 2, 175(2016), DOI: $10.1016 /$ j.reffit.2016.09.004

3. A. Azimi, A. Azari, M. Rezakazemi, M. Ansarpour, Chem. Bio. Eng. Review., 4, 1(2017), DOI: $10.1002 /$ cben. 201600010

4. F. Fu, Q. Wang, J. Environ. Manage., 92, 407(2011), DOI:10.1016/j.jenvman.2010.11.011

5. A. A. Oladipo, M. A. Abureesh, M. Gaz, Int. J. Biol. Macromol.,90, 89(2016), DOI:10.1016/j.ijbiomac.2015.08.054

6. E. Yagmur, M. Ozmak, Z. Aktas, Fuel, 87, 3278(2008), DOI:10.1016/j.fuel.2008.05.005

7. Y. Maa, X. Lia, H. Mao, B. Wanga, P. Wang, Chem. Eng. J., 353,410(2018), DOI:10.1016/j.cej.2018.07.131

8. EI. El-Shafey, M. Cox, A.A. Pichugin, Q. Appleton, J. Chem. Technol. Biotechnol., 77(4), 429 (2002), DOI:10.1002/jctb.577

9. A. Singh, S.M. Prasad, Int. J. Environ.Sci. Technol., 12,353(2015), DOI:10.1007/s13762-014-0542-y

10. H.A. Hegazi, HBRC J., 9, 276 (2013), DOI:10.1016/j.hbrcj.2013.08.004

11. M. Saifuddin and P. Kumaran, Elect. J. Biotech., 8, 43 (2005).

12. K. Kadirvelu, Thamaraiselvi, K. Namasivayam, Bioresour. Technol., 76(1), 63(2001), DOI: 10.1016/S0960-8524(00)00072-9

13. V.K. Gupta, Suhas, J. Environ. Manage., 90, 2313 (2009), DOI:10.1016/j.jenvman.2008.11.017

14. J. Li, L. Zheng, H. Liu, J. Porous. Mater., 24, 1575 (2017), DOI:10.1007/s10934-017-0397-y

15. M. Karnib, A. Kabbani, H. Holail, Z. Olama, Energy Proce., 50, 113(2014), DOI: 10.1016/j.egypro.2014.06.014

16. A. Bhatnagar, W. Hogland, M.Marques, M. Sillanpaa, Chem. Eng. J., 219, 499(2013), DOI: 10.1016/j.cej.2012.12.038

17. Q. Liu, T. Zheng, P. Wang, J. Jiang, N. Li, Chem. Eng. J., 157, 348(2010), DOI:10.1016/j.cej.2009.11.013

18. K. P. Singh, D. Mohan, S. Sinha, G.S. Tondon, D. Gosh, Ind. Eng. Chem. Res., 42(9),1965 (2003), DOI: $10.1021 / \mathrm{ie} 020800 \mathrm{~d}$

19. J.T. Nwabanne and P.K. Igbokwe, Inter. J. Multi. Sci. Eng., 3, 46 (2012).

20. P. N. Kamble, R.G. Bodade, A.K. Sagar, G.M. Pondhe, V.B. Gaikwad, A.V. Mane, Natur. Environ. Pollut. Tech., 17, 215(2018).

21. M. Kobya and E. Demirbas Senturk, M. Ince, Bioresour. Technol., 96, 1581(2005), DOI: 10.1016/j.biortech.2004.12.005

22. H.M. Boehm, Carbon, 32,759 (1994), DOI:10.1016/0008-6223(94)90031-0

23. H. Abiko, M. Furuse, T. Takano, Indus Health, 48, 427 (2010), DOI:10.2486/indhealth.ms 1041

24. Y. H. Yoon, J.H. Nelson, Am. Ind. Hyg. Assoc. J., 45, 509(1984a), DOI: $10.1080 / 15298668491400205$

25. Y. H. Yoon, J. H. Nelson, Am. Ind. Hyg. Assoc. J., 45, 517(1984b), DOI:10.1080/15298668491400197

26. L. Zhou, M. Li, Y. Sun, Y. Zhou, Carbon, 39,771 (2001), DOI:10.1016/S0008-6223(01)00025-2. 
RASĀYAN J. Chem.

Vol. 12 | No. 4 |1864 - 1871| October - December | 2019

27. S. Rengaraj, M. Seung-Hyeon, R. Sivabalan, B. Arabindoo, V. Murugesan, Waste Manag., 22,543 (2002), DOI:10.1016/S0956-053X(01)00016-2

28. G.O. El-Sayed, Desalination, 272, 225(2011), DOI:10.1016/j.desal.2011.01.025

29. A. K. Kushwaha, N. Gupta, M.C. Chattopadhyaya, Arab. J. Chem., 10, 51645(2017), DOI: $10.1016 /$ j.arabjc. 2013.06 .007

30. B. Shrestha, J. Kour, K.N. Ghimire, Adv. Chem. Eng. Sc., 6, 525(2016), DOI: $10.3126 /$ njst.v13i2.7722

31. M. B. Desta, J. Therm., 1(2013), DOI:10.1155/2013/375830

32. E. Erdem, N. Karapinar, R. Donat, J. Colloid. Interface Sci., 280, 309(2004), DOI: $10.1016 /$ j.jcis.2004.08.028

33. X. Wu, F. Zhao, M. Chen, Y. Zhang, C. Zhao, H. Zhou, Adso. Scie. Tech., 26, 145(2008), DOI: $10.1260 \% 2 \mathrm{~F} 026361708786036115$

34. E. El-Ashtoukhy, N. Amin, O. Abdelwahab, Desalination, 223, 162(2008), DOI:10.1016/j.desal.2007.01.206

[RJC-5324/2019] 